\title{
Assessment of Liver Morbidity in Breast Cancer Patients Receiving Chemotherapy in Suez Canal University Hospitals
}

\author{
Mahmoud M. Sheded MD ${ }^{1}$; Adel A. Hassan, $\mathrm{MD}^{2}$; Ehab M. Hassanein, $\mathrm{MD}^{3}$ \\ and Nageh L. Mahrous MD, ${ }^{1}$ \\ ${ }^{1}$ Infectious and Endemic Hepatology and Gastroenterology Department, Faculty of Medicine, \\ Suez University, Egypt \\ ${ }^{2}$ Infectious Diseases Department, Faculty of Medicine, Suez Canal University, Egypt \\ ${ }^{3}$ Oncology and Nuclear medicine Department, Faculty of Medicine, Suez Canal University, Egypt
}

Corresponding Author Mahmoud Sheded

Mobile:

01224337370

E mail:

mahmoudsheded@gm ail.com

Key words: Liver, Morbidity, Breast ,cancer
Background and study aim: In Egypt, breast cancer, representing $18.9 \%$ of total cancer cases and $35.1 \%$ of cancer in women. Potential interactions between the liver and chemotherapy fall into direct chemotherapy-induced hepatotoxicity and Potentiation of preexisting liver disease, especially viral hepatitis. The aim of the study is to assess liver morbidity in breast cancer patients before and 3 months after chemotherapy to assess reactivation of viral hepatitis.

Subjects and Methods: This study is prospective study; It included 88 female patients who received chemotherapy for breast cancer.

Results: Before chemotherapy 9 patients (10.2\%) \& 11 patients (12.5\%) had elevated ALT \& AST respectively which increased after chemotherapy to 32 patients (36.4\%) \& 29 patients $(33 \%)$ respectively. Two

\section{INTRODUCTION}

In Egypt, breast cancer (BC) is the most common cancer among women, representing $18.9 \%$ of total cancer cases and $35.1 \%$ of cancer in women. Breast cancer patients receiving therapy require supportive care for the prevention and management of physical and psychosocial adverse effects of cancer and its treatments [1]. Patients undergoing cytotoxic chemotherapy require careful assessment of liver function both prior to and during therapy. Potential interactions between the liver and chemotherapy fall into two categories: Direct chemotherapy-induced hepatotoxicity and potentiation of preexisting liver disease, especially viral hepatitis [2]. Druginduced liver injury (DILI) has an patients $(2.3 \%)$ had low serum albumin which increased after chemotherapy to 18 patients $(20.5 \%)$. None of the patients had elevated S. bilirubin, ascites or jaundice, while after chemotherapy 10 patients (11.4\%) had elevated S. bilirubin, 5 patients $(5.6 \%)$ and 6 patients $(6.8 \%)$ developed ascites and jaundice respectively. Regarding Child score: None of the patients had Child B/C score before treatment, while after chemotherapy 6 patients (6.8\%) developed Child B/C score. Regarding viral hepatitis, 2 of ten patients $(20 \%)$ who were $\mathrm{HBcIgG}$ positive, $\mathrm{HBsAg}$ negative with undetectable HBV DNA by PCR developed evidence of HBV reactivation in form of positive PCR for both \& reversion of HBsAg for one patient.

Conclusion: Chemotherapy for breast cancer carries high risk for hepatotoxicity and reactivation of viral hepatitis

estimated annual incidence between 10 and 15 per 10,000 to 100,000 persons exposed to prescription medications. DILI accounts for approximately $10 \%$ of all cases of acute hepatitis, and it is the most common cause of acute liver failure in the United States [3].

Viral hepatitis reactivation is one of the major challenges encountered during a variety of chemotherapy treatments. In the literature, there is a well-established association between hepatitis B virus (HBV) reactivation and some anti-cancer drugs, especially monoclonal antibodies. On the other hand, there is limited data concerning the reactivation of hepatitis 
$\mathrm{C}$ virus (HCV) with chemotherapeutic drugs and targeted therapies [4].

\begin{abstract}
Aim of the work:
To assess liver morbidity in breast cancer patients before and 3 months after chemotherapy to assess reactivation of viral hepatitis.
\end{abstract}

\section{PATIENTS AND METHODS}

\section{Patients:}

After approval of our ethics committee, this prospective study was performed in Oncology \& nuclear medicine department at Suez Canal University hospital, Ismailia from June 2011 to December 2012. It included 88 breast cancer patients who consecutively attended the Oncology \& Nuclear Medicine Department to receive chemotherapy during the study period.

\section{Methods:}

The chemotherapeutic regimens of each patient were given according to the standard protocol for the specific tumor type.

Liver profile (ALT, AST, Bilirubin, Albumin, PT \& INR, and ultrasonography were done for all patients before starting chemotherapy, Tri-phasic CT abdomen were done if there were focal hepatic lesions \& then 3 months after completing chemotherapy.

Viral markers (HBsAg, HBsAb, \& Anti-HBcIgG, $\mathrm{HCV} \mathrm{Ab}$ ) were done for all consecutive breast cancer patients who received cytotoxic chemotherapy.

Patients who were positive for $\mathrm{HCV} \mathrm{Ab}$ were subjected to HCV DNA by PCR to detect active viral replication \& viremia.

Patients who were positive for HBsAg or HBcIgG were subjected to HBV DNA by PCR to detect active viral replication \& viremia.

All patients included in the study were subjected for:

\section{A- History taking :}

Including personal, socio-demographic data, and present illness (age, sex, blood transfusion, past surgical procedure, intravenous drug abuse, jaundice, past or family history of viral hepatitis, and family history of viral hepatitis or breast cancer).

\section{B- Laboratory tests:}

1. Serum samples were collected for measurement of HBV DNA before starting chemotherapy (For $\mathrm{HbsAg}$ or $\mathrm{HBcAg}$ positive patients).
2. Serum biochemistry including albumin, prothrombin time, total bilirubin, alanine transaminase (ALT) and aspartate transaminase (AST) \& CBC were carried out before starting therapy then 3 months after cessation of chemotherapy [4,5\&6]

3. For patients who developed hepatitis (as defined later) during the course of chemotherapy, they were classified into three groups (group I for positive HBV patients, group II for positive HCV patients, \& group III for negative $\mathrm{HBV}$ and $\mathrm{HCV}$ patients).

4. For patients with positive $\mathrm{HBsAg}, \mathrm{HBcIgG}$ or HCV Ab, HBV DNA by PCR \& HCV RNA by PCR was measured.

5. Hepatitis $\mathrm{C}$ reactivation was defined as an increase of HCV-RNA viral load greater than $1 \log _{10} \mathrm{IU} / \mathrm{mL}$ and/or at least a threefold increase in serum ALT in HCV infected patients [7\&8].

6. Hepatitis was attributed to HBV reactivation when there was an increase in HBV DNA levels of $\geq 10$ - fold when compared with baseline HBV DNA levels or the appearance of HBV DNA from an undetectable level at baseline or an absolute increase of $\mathrm{HBV}$ DNA level that exceeded 1,000,000,000 genome equivalents/ml (GE/ml) during chemotherapy $[\mathbf{9 , 1 0 ]}$.

7. Hepatitis was defined as a threefold or greater increase in serum ALT that exceeds the reference range $(>45 \mathrm{IU} / \mathrm{L})$ or an absolute increase of ALT to >100 IU/L [5,7].

8. All patients who developed HBV reactivation received Tenofovir as a therapeutic measure [11-15].

9. Morbidity related to $\mathrm{HBV}$ or $\mathrm{HCV}$ reactivation was recorded.

\section{RESULTS}

This study revealed a significant liver morbidity in breast cancer patients who were treated with chemotherapy.

Regarding socio-demographic characteristics: Mean age of patients was $50 \pm 11.1$ years. Most of the patients (74 patients (84\%)) are married. 66 patients $(75 \%)$ came from urban areas, and 72 patients $(82 \%)$ were un-employed. Regarding to their special habits, only one patient was smoker and no one was alcoholic (Table 1). 


\section{Regarding HBV \& HCV :}

$11(12.5 \%)$ patients were HBV positive, while 9 $(10.2 \%)$ patients were $\mathrm{HCV}$ positive. Before chemotherapy 9 patients $(10.2 \%) \& 11$ patients (12.5\%) had elevated ALT \& AST respectively which increased after chemotherapy to 32 patients $(36.4 \%) \& 29$ patients (33\%) respectively with significant P-value. Two patients (2.3\%) had low serum albumin which increased after chemotherapy to 18 patients $(20.5 \%)$ with significant $\mathrm{P}$-value. None of the patients had elevated S. bilirubin; while after chemotherapy 10 (11.4\%) had elevated S. bilirubin with significant P-value. Also none of the patients had ascites or jaundice before chemotherapy, while after chemotherapy 5 patients (5.6\%) \& 6 patients $(6.8 \%)$ developed ascites and jaundice respectively.

Regarding Metastatic HFLs, 5 patients (5.7\%) had MHFLs before chemotherapy; while after chemotherapy 9 patients $(10.2 \%)$ had MHFLs. 7 patients $(8 \%)$ had splenomegaly before treatment which became 8 patients (9\%) after chemotherapy.

\section{Regarding Child score:}

None of the patients had child B/C score before treatment, while after chemotherapy 6 patients (6.8\%) developed child $\mathrm{B} / \mathrm{C}$ score (Table 2).

\section{Regarding symptoms :}

We found that 23 patients $(26.4 \%)$ had loss of weight \& appetite before chemotherapy which increased to 66 patients $(76 \%)$ after chemotherapy with significant $\mathrm{P}$-Value $(<0.01), 15$ patients $(17 \%)$ had easy fatigability which increased to 73 patients (83\%) after chemotherapy with significant P-Value $(<0.01)$, and 20 patients $(22.7 \%)$ had dyspepsia which increased to 62 patients $(70.5 \%)$ after chemotherapy with significant P-Value $(<0.01)$. Regarding breast cancer symptoms (Pain, Skin changes, Nipple discharge), none of them showed significant change after chemotherapy (Table 3, Figure 1).

\section{Regarding HBV patients:}

Before treatment, one patient had Positive HbsAg with positive HBV DNA by PCR \& was treated by Tenofovir $300 \mathrm{mg}$ once daily and after treatment her HBV DNR by PCR showed negative result. Ten people had positive $\mathrm{HbcIgG} \&$ negative $\mathrm{HBsAg}$ before treatment, nine of them had negative HBV DNA by PCR and only one patient had positive HBV DNA by PCR \& was treated by tenofovir $300 \mathrm{mg}$ once daily and recheck of HBV DNA by PCR after finishing chemotherapy showed negative result.
However, 2 new cases (HbcIgG positive, $\mathrm{HBsAg}$ negative \& HBV DNA PCR negative before Treatment) showed a positive PCR levels after chemotherapy for their breast cancer with mean of $48254 \mathrm{IU} / \mathrm{ml}$, and one of them had positive HBsAg, for them treatment with tenofovir 300 mg once daily was started (Table 4).

\section{Regarding Liver morbidity in HBV patients:}

Before chemotherapy 2 patients $(10.2 \%)$ had elevated ALT \& AST respectively which increased after chemotherapy to 7 patients $(63.6 \%) \& 5$ patients $(45.5 \%)$ respectively. None of the patients had low serum albumin or elevated S. bilirubin before chemotherapy, while after treatment 5 patients $(45.5 \%)$ had low level of serum albumin \& 3 patients (27.3\%) had elevated serum bilirubin. Also none of the patients had ascites or jaundice before chemotherapy, while after chemotherapy 1 patient $(9.1 \%) \& 2$ patients $(18.2 \%)$ developed ascites and jaundice respectively.

Regarding Child score: None of the patients had Child B/C score before treatment, while after chemotherapy 2 patients (18.2\%) developed child $\mathrm{B} / \mathrm{C}$ score (Table 5).

\section{Regarding HCV patients:}

Before chemotherapy treatment, 9 patients had positive result for $\mathrm{HCV} \mathrm{Ab}$, from whom 1 patient completed antiviral therapy with DAAS since 3 years and achieved SVR, 2 patients had negative HCV RNA by PCR, while the other 6 patients had positive HCV RNA by PCR with mean of $698352 \mathrm{IU} / \mathrm{ml}$ which increased to $2609409 \mathrm{IU} /$ $\mathrm{ml}$ after chemotherapy (Table 4).

\section{Regarding Liver morbidity in HCV patients:}

Before chemotherapy 3 patients $(33.3 \%)$ had elevated ALT \& 4 patients (44.4\%) had elevated AST respectively which increased after chemotherapy to 7 patients $(77.8 \%)$ with significant Pvalue. None of the patients had low serum albumin or elevated S. bilirubin before chemotherapy, while after treatment 5 patients $(55.6 \%)$ had low level of serum albumin $\& 5$ patients $(55.6 \%)$ had elevated serum bilirubin. Also none of the patients had ascites or jaundice before chemotherapy, while after chemotherapy 4 patient $(44.4 \%) \& 4$ patients $(44.4 \%)$ developed ascites and jaundice respectively with significant $\mathrm{P}$-value.

Regarding Child score: None of the patients had Child B/C score before treatment, while after chemotherapy 4 patients (44.4\%) developed Child B/C score (Table 6). 
Table (1): Sociodemographic characteristics of studied sample $(\mathrm{n}=88)$

\begin{tabular}{|l|c|}
\hline \multicolumn{1}{|c|}{ Variables } & $\mathbf{n}=\mathbf{8 8}$ \\
\hline Age, yrs & $49.8(11.1)$ \\
\hline Residence, $\mathbf{n}(\%)$ & \\
\hline Urban & $66(75)$ \\
Rural & $22(25)$ \\
\hline Marital status, $\mathbf{n}(\%)$ & \\
\hline Married & $74(84.1)$ \\
Divorced & $3(3.4)$ \\
Widow & $11(12.5)$ \\
\hline Occupation, $\mathbf{n}(\%)$ & \\
\hline Employer & $9(10.2)$ \\
Manual Worker & $6(6.8)$ \\
Farmer & $1(1.1)$ \\
Un employed & $72(81.8)$ \\
\hline Smoker, $\mathbf{n}(\%)$ & $1(1.1)$ \\
\hline Alcoholics, $\mathbf{n}(\%)$ & 0 \\
\hline
\end{tabular}

Table (2) : Comparison between patients before and after chemotherapy regarding liver morbidity

\begin{tabular}{|l|c|c|c|}
\hline \multicolumn{1}{|c|}{ Variables } & $\begin{array}{c}\text { Before } \\
\text { Chemotherapy }\end{array}$ & $\begin{array}{c}\text { After } \\
\text { Chemotherapy }\end{array}$ & P-Value \\
\hline Elevated ALT $(>40-\mathrm{ULN})$ & $9(10.2 \%)$ & $32(36.4 \%)$ & $<0.01^{*}$ \\
\hline Elevated AST $(>40-\mathrm{ULN})$ & $11(12.5 \%)$ & $29(33 \%)$ & $<0.01^{*}$ \\
\hline Low S.Albumin $(<3.5 \mathrm{~g} / \mathrm{dl})$ & $2(2.3 \%)$ & $18(20.5 \%)$ & $<0.01^{*}$ \\
\hline Elevated S. Bilirubin $(>1.2 \mathrm{mg} / \mathrm{dl})$ & 0 & $10(11.4 \%)$ & $<0.01^{*}$ \\
\hline Prolonged PT. INR(>1.2) & $1(1.1 \%)$ & $3(3.4 \%)$ & 0.5 \\
\hline Ascites & 0 & $5(5.6 \%)$ & $<0.01^{*}$ \\
\hline Jaundice & 0 & $6(6.8 \%)$ & $<0.01^{*}$ \\
\hline Metastatic HFL & $5(5.6 \%)$ & $9(10.2 \%)$ & 0.125 \\
\hline Splenomegaly (>13cm) & $7(8 \%)$ & $8(9.1 \%)$ & 0.344 \\
\hline Child Score (B/C) & 0 & $6(6.8 \%)$ & $<0.01^{*}$ \\
\hline
\end{tabular}

$\mathrm{P}$ - values are based on Wilcoxon Signed Ranks test. Statistical significance at $\mathrm{P}<0.05$ 
Table (3): Group comparison between patients before and after chemotherapy according their clinical presentation

\begin{tabular}{|l|c|c|c|}
\hline \multirow{2}{*}{ Variables } & \multicolumn{2}{c|}{ Chemotherapy } & \multirow{2}{*}{ p- value } \\
\cline { 2 - 3 } & Before & After & \\
\hline Loss of weight and Appetite & $23(26.4)$ & $66(75.9)$ & $<\mathbf{0 . 0 1 *}$ \\
\hline Breast cancer symptoms & & & \\
Pain & $19(21.6)$ & $20(25)$ & 0.58 \\
Nipple discharge & $6(6.8)$ & $1(1.1)$ & 0.9 \\
Skin changes & $4(4.5)$ & $1(1.1)$ & 0.37 \\
\hline Lower limb edema & 0 & $21(23.9)$ & $<\mathbf{0 . 0 1} *$ \\
\hline Jaundice & 0 & $6(6.8 \%)$ & $<\mathbf{0 . 0 1} *$ \\
\hline Diarrhea & $3(3.4)$ & $28(31.8)$ & 0.24 \\
\hline Bleeding tendency & 0 & $5(5.7)$ & $<\mathbf{0 . 0 1 *}$ \\
\hline Constipation & $3(3.4)$ & $9(13.6)$ & $\mathbf{0 . 0 1 2}$ \\
\hline Easy fatigability & $15(17)$ & $73(83)$ & $<\mathbf{0 . 0 1 *}$ \\
\hline Itching & $2(2.3)$ & $10(11.4)$ & $<\mathbf{0 . 0 1 *}$ \\
\hline Nausea & $11(12.5)$ & $51(58)$ & $<\mathbf{0 . 0 1 *}$ \\
\hline Vomiting & $6(6.8)$ & $13(14.8)$ & $\mathbf{0 . 0 1 6}$ \\
\hline Dyspepsia & $20(22.7)$ & $62(70.5)$ & $<\mathbf{0 . 0 1 *}$ \\
\hline Abdominal distention & 0 & $5(5.6 \%)$ & $<\mathbf{0 . 0 1 *}$ \\
\hline
\end{tabular}

$* \mathrm{P}$ values are based on McNemar test. Statistical significance at $\mathrm{P}<0.05$

Table (4): Clinical data of patients related to viral hepatitis

\begin{tabular}{|c|c|}
\hline \multicolumn{1}{|c|}{ Variables } & $\mathbf{n}=\mathbf{8 8}$ \\
\hline Hepatitis B, $\mathbf{n}(\%)$ & $11(12.5)$ \\
\hline Before chemotherapy & \\
\hline HBs Ab & $1(1.1)$ \\
HBs Ag & $1(1.1)$ \\
HBc IgG & $10(11.4)$ \\
Qualitative HBV DNA PCR positive & $2(2.3)$ \\
Quantitative HBV DNA PCR, mean (SD) & $337(771)$ \\
\hline HBV treatment & $2(2.3)$ \\
\hline Tenofovir 300 & \\
\hline After chemotherapy & $1(1.1)$ \\
\hline HBs Ab & $2(2.3)$ \\
HBs Ag & $10(11.4)$ \\
HBc IgG & $2(2.3)$ \\
Qualitative HBV DNA PCR positive & $48254(116309)$ \\
\hline Quantitative HBV DNA PCR, mean (SD) & $9(10.2)$ \\
\hline Before chemotherapy & $6(6.8)$ \\
\hline Qualitative HCV DNA PCR positive & \\
Quantitative HCV DNA PCR, mean (SD) & $698352(1113003)$ \\
\hline After chemotherapy & $6(6.8)$ \\
\hline Qualitative HCV DNA PCR positive & $14(15.9)$ \\
\hline Quantitative HCV DNA PCR, mean (SD) IU/ ml & $2609409(4122140)$ \\
\hline
\end{tabular}


Table (5): Comparison between HBV patients before and after chemotherapy regarding liver morbidity

\begin{tabular}{|l|c|c|c|}
\hline \multicolumn{1}{|c|}{ Variables } & $\begin{array}{c}\text { Before Chemotherapy } \\
(\mathbf{n = 1 1})\end{array}$ & $\begin{array}{c}\text { After Chemotherapy } \\
(\mathbf{n = 1 1})\end{array}$ & P-Value \\
\hline Elevated ALT $(>40-\mathrm{ULN})$ & $2(18.2 \%)$ & $7(63.6 \%)$ & $<0.01^{*}$ \\
\hline Elevated AST $(>40-\mathrm{ULN})$ & $2(18.2 \%)$ & $5(45.5 \%)$ & $<0.01^{*}$ \\
\hline Low S.Albumin(<3.5g/dl) & 0 & $5(45.5 \%)$ & $<0.01^{*}$ \\
\hline Elevated S.Bilirubin $(>1.2 \mathrm{mg} / \mathrm{dl})$ & 0 & $3(27.3 \%)$ & $<0.01^{*}$ \\
\hline Prolonged PT. INR $(>1.2)$ & $1(9.1 \%)$ & $2(18.2 \%)$ & 1 \\
\hline Ascites & 0 & $1(9.1 \%)$ & 1 \\
\hline Jaundice & 0 & $2(18.2 \%)$ & $<0.01^{*}$ \\
\hline Metastatic HFL & 0 & 0 & 1 \\
\hline Splenomegaly(>13cm) & $2(18.2 \%)$ & $2(18.2 \%)$ & $<0.01^{*}$ \\
\hline Child B/C Score & 0 & $2(18.2 \%)$ & $<$ \\
\hline
\end{tabular}

* $\mathrm{P}$ values are based on McNemar test or Wilcoxon Signed Ranks test as appropriate. Statistical significance at $\mathrm{P}<0.05$

Table (6): Comparison between HCV patients before and after chemotherapy regarding liver morbidity

\begin{tabular}{|l|c|c|c|}
\hline \multicolumn{1}{|c|}{ Variables } & $\begin{array}{c}\text { Before Chemotherapy } \\
(\mathbf{n = 9})\end{array}$ & $\begin{array}{c}\text { After Chemotherapy } \\
(\mathbf{n = 9})\end{array}$ & P-Value \\
\hline Elevated ALT $(>40-\mathrm{ULN})$ & $3(33.3 \%)$ & $7(77.8 \%)$ & $<0.01^{*}$ \\
\hline Elevated AST $(>40-\mathrm{ULN})$ & $4(44.4 \%)$ & $7(77.8 \%)$ & $<0.01^{*}$ \\
\hline Low S.Albumin $(<3.5 \mathrm{~g} / \mathrm{dl})$ & 0 & $5(55.6 \%)$ & $<0.01^{*}$ \\
\hline Elevated S.Bilirubin $(>1.2 \mathrm{mg} / \mathrm{dl})$ & 0 & $5(55.6 \%)$ & $<0.01^{*}$ \\
\hline Prolonged PT. INR $(>1.2)$ & $1(11.1 \%)$ & $2(22.2 \%)$ & 1 \\
\hline Ascites & 0 & $4(44.4 \%)$ & $<0.01^{*}$ \\
\hline Jaundice & 0 & $4(44.4 \%)$ & $<0.01^{*}$ \\
\hline Metastatic HFL & $1(11.1 \%)$ & $3(33.3 \%)$ & $<0.01^{*}$ \\
\hline Splenomegaly $(>13 \mathrm{~cm})$ & $3(33.3 \%)$ & $3(33.3 \%)$ & 1 \\
\hline Child B/C Score & 0 & $4(44.4 \%)$ & $<0.01^{*}$ \\
\hline
\end{tabular}

* $\mathrm{P}$ values are based on McNemar test or Wilcoxon Signed Ranks test as appropriate. Statistical significance at $\mathrm{P}<0.05$

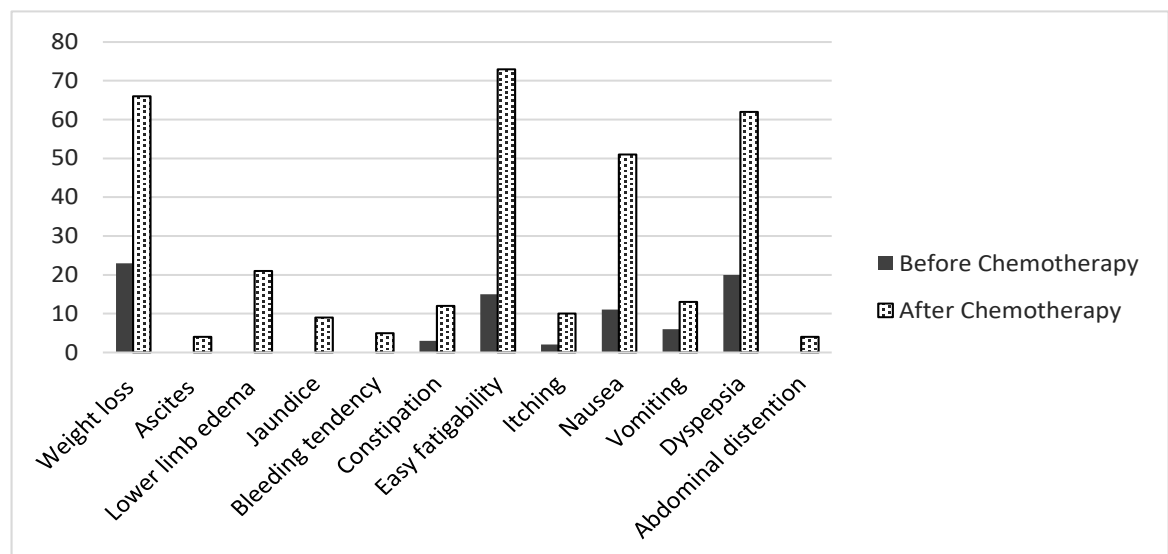

Fig1. Shows different clinical presentation in breast cancer patients before and after receiving chemotherapy 


\section{DISCUSSION}

This study is prospective observational analytical study about assessment of liver morbidity in breast cancer patients receiving chemotherapy in Suez Canal University Hospital. A total of 88 patients with breast cancer who consecutively attended the Oncology \& nuclear medicine department to receive chemotherapy during study period were enrolled in this study at the oncology and nuclear medicine department in Suez Canal University hospitals during the period between June 2016 and December 2017.

The mean age ranged between 29 and 73 years old (mean $=49.8$ ), all patients were females, agreeing with a study conducted by Ahn ., et al. with the same mean age of 46, however Assis, et al. reported a lower mean age of 42 years [4\&10]..

In this study: most of patients were belonging to urban areas $75 \%$, while Chauhan et. el. reported that $66 \%$ of patients were living in rural area [5]. Also most of the patients were not working $(81.8 \%)$ and married $(84 \%)$, this explained by the socio-demographic characterestics of Ismailia city

In agreement with other studies that reported hepatotoxicity of chemotherapy for breast cancer patients, Potential interactions between the liver and chemotherapy fall into two categories: Direct chemotherapy-induced hepatotoxicity and potentiation of preexisting liver disease, especially viral hepatitis or Drug-induced liver injury (DILI).

Before starting chemotherapy $10.2 \% \& 12.5 \%$ of patients reported elevated ALT \& AST respectively which increased after chemotherapy to $36.4 \%$ \& $33 \%$ respectively with the mean of ALT \& AST increased from $31.74 \& 32.53 \mathrm{IU} / \mathrm{ml}$ before chemotherapy to $46.6 \& 47.94 \mathrm{IU} / \mathrm{ml}$ respectively after chemotherapy, which agree with Ahn .,et. al. who reported that $12.3 \%$ of breast cancer patients had abnormalities in LFT before chemotherapy which increased to $34.8 \%$ after chemotherapy $[3,4 \& 5]$.

Also total S. bilirubin elevated in $11.4 \%$ of patients, the mean value of total S. bilirubin increased from $0.61 \mathrm{mg} / \mathrm{dl}$ before starting chemotherapy to 1.07 $\mathrm{mg} / \mathrm{dl}$ after chemotherapy, in agree with Chauhan et. al. who reported the mean value of total bilirubin was $0.30 \pm 1.3 \mathrm{mg} / \mathrm{dl}$ before the starting of the treatment which increased after chemotherapy to $1.12 \mathrm{mg} / \mathrm{dl}$ [5].
While percentage of patients who had low level of s. albumin markedly increased from $2.3 \%$ to $20.5 \%$ after chemotherapy and the mean value of S. albumin decreased from $4.07 \mathrm{gm} / \mathrm{dl}$ before chemotherapy to $3.77 \mathrm{gm} / \mathrm{dl}$ after chemotherapy, in agreement with authors found that low levels of serum albumin may be related to many factors as biological stress, liver dysfunction, and decrease mass of visceral protein or ability of albumin synthesizing. Also association with marked malnutrition [5,16,17\&18]

In agreement with Swati et. al. who found significant decrease in all components of CBC before \& after chemotherapy. The $\mathrm{Hb}$ level decreased from $11.97 \mathrm{~g} / \mathrm{L}$ to $10.66 \mathrm{~g} / \mathrm{L}$, also WBC count decreased from $6.65 \times 103 / \mathrm{mm} 3$ to $4.25 \times 103 / \mathrm{mm} 3$, while PLT count decreased from $269.98 \times 103 / \mathrm{mm}^{3}$ to $201.39 \times 103 / \mathrm{mm}^{3}$ after chemotherapy, due to different pathological causes like drug toxicity, pathogenesis of cancer and nutritional factors [6].

Only one patient of studied patients $(1.1 \%)$ was HBsAg positive, it agrees with Pattullo who reported that $1 \%$ of patients were $\mathrm{HBsAg}$ positive during screening of solid cancer patients [11], while this results was markedly lower than that reported by Alessandro et al, in Italy and Kawsar et al, in Greece (4.8\% and $5.4 \%$ in respectively) $[12,13]$, this difference explained by the higher prevalence of $\mathrm{HBV}$ in community of these studies than our community.

Ten patients (11.3\%) were HBsAg negative/anti$\mathrm{HBc}$ positive which is slightly lower than that $(12 \%)$ reported by Pattullo[11]. while markedly lower than that reported by Kawsar et al., in a survey performed in Greece, who found $\mathrm{HBsAg}$ negative/anti-HBc positive in $40 \%$ of cancer patients $[12,13]$.

Two of ten patients (20\%) who were HBsAg negative/anti-HBc positive before chemotherapy developed HBV reactivation with positive HBV DNA PCR during follow up after chemotherapy, In comparison with other studies, Alessandro et. al. reported that none of the patients who were inactive HBsAg carrier or had an occult HBV infection presented with HBV reactivation [12], while Tang et. al. reported that the rate of HBV reactivation is higher in patients with breast cancer $(41-56 \%)$ than in those treated for other solid tumors (14-21\%), also Yoo et. al. reported high rates of $\mathrm{HBV}$ reactivation, $38 \%-54 \%$ in HBV positive patients who undergo hematopoietic stem-cell trans-plantation and treatment for hematological malignancy, especially malignant

Sheded et al., Afro-Egypt J Infect Endem Dis 2019; 9(1):3-11

https://aeji.journals.ekb.eg/

http://mis.zu.edu.eg/ajied/home.aspx 
lymphoma. These numerical differences are possibly due to the type or intensity of chemotherapy used for these conditions, rather than the nature of the malignancy itself and to the type of $\mathrm{HBV}$ infection [14,15].

Regarding HCV patients: Nine patients (10.2\%) had positive result for $\mathrm{HCV} \mathrm{Ab}$, before treatment from whom 1 patient completed antiviral therapy with DAAS since 3 years and achieved SVR, 2 patients had negative HCV RNA by PCR, while the other 6 patients had positive HCV RNA by PCR with mean of 698352 IU/ ml which increased to $2609409 \mathrm{IU} / \mathrm{ml}$ after chemotherapy. While Miura et. al. in a retrospective survey of patients diagnosed with breast cancer in Japan reported that 20 patients $(2 \%)$ were $\mathrm{HCV} \mathrm{Ab}$ positive; this difference may be due to difference of HCV prevalence between Egypt \& Japan [7]. Also Miura et. al. reported no difference in $\mathrm{HCV}$ RNA PCR before after chemotherapy with median serum HCV-RNA level at baseline and after chemotherapy was 6.4 and $6.5 \log \mathrm{IU} / \mathrm{ml}$, respectively. While Coppola et. al. showed that rituximab-based chemotherapy resulted in an increase in HCV-RNA at least $1.5 \log \mathrm{IU} / \mathrm{ml}$ followed by hepatic flare among patients with lymphoma[8]. These numerical differences are possibly due to the type or intensity of chemotherapy used for these conditions, rather than the nature of the malignancy itself and to the type of $\mathrm{HCV}$ infection [15].

\section{CONCLUSION}

Chemotherapy for breast cancer carries high risk for hepatotoxicity. Hepatotoxicity and liver morbidity is more common in patients with viral hepatitis and liver disease before starting chemotherapy, with probability of reactivation of HBV and HCV infections after chemotherapy. Prophylactic antiviral therapy by Tenofovir 300 mg once daily decreases risk of $\mathrm{HBV}$ reactivation.

\section{Ethical approval}

Consent for an interview was taken from each participant, who was assured about the confidentiality of his information. The faculty of medicine Suez Canal University research ethics committee approved the study .

\section{Funding}

\section{None.}

\section{Conflicts of interest}

There are no conflicts of interest.

11- Pattullo V. Hepatitis B reactivation in the setting of chemotherapy and immunosuppression -

\section{REFERENCES}

1- El-Bolkainy M.N. Topographic pathology of cancer, 2nded. Cairo, National Cancer Institute, Cairo University 2000: 87.

2- Lee W.M. Drug-induced hepatotoxicity. $N$ Engl J. Med 2003; 349:474.

3- Björnsson ES, Bergmann OM, Björnsson HK, Kvaran RB, Olafsson S. Incidence, presentation, and outcomes in patients with drug-induced liver injury in the general population of Iceland. Gastroenterology 2012; 144:1419.

4- Ahn JH, Kim SB, Yun MR, Lee JS, Kang YK, Kim WK. Alternative Therapy and Abnormal Liver Function during Adjuvant Chemotherapy in Breast Cancer Patients. J Korean Med Sci 2004; 19: 397-400.

5- Chauhan P., Yadav R., Kaushal V., Beniwal P. Evaluation of serum biochemical profile of breast cancer patients. International Journal of Medical Research \& Health Sciences 2016; 5, 7:1-7

6- Swati S., Neelima S., Akshay., Sanjay S., Reetika S., Sarvesh K. Comparative study of hematological parameters along with effect of chemotherapy and radiotherapy in different stages of breast cancer. International Journal of Research in Medical Sciences 2017; 5 , 1: 311.

7- Miura Y., Richard L., Yoichi N., Koichi S., Akihiko S., Tsuguo I., et. al. The Safety of Chemotherapy for Breast Cancer Patients with Hepatitis C Virus Infection. J. Cancer 2013; 4(6):519-523.

8- Coppola N., Pisaturo M., Guastafierro S. Tonziello G, Sica A, Iodice V, et. al. Increased hepatitis $\mathrm{C}$ viral load and reactivation of liver disease in HCV RNA-positive patients with onco-haematological disease undergoing chemotherapy. Dig Liver Dis 2012; 44:49-54

9- Wang Y, Luo XM, Yang D, Zhang J, Zhuo HY, Zhang J, et al. Testing for hepatitis B infection in prospective chemotherapy patients: a retrospective study. World J. Gastroenterol 2013; 19:923-930.

10- Assis DR., Simone T., João R., David S., Paulo R. Characteristics of an Outpatient Chronic Hepatitis B Virus Infection Cohort. Einstein (Sao Paulo, Brazil)2015; 13(2) : 189-95.

prevention is better than cure. World Journal of Hepatology 2015;7:954-67

Sheded et al., Afro-Egypt J Infect Endem Dis 2019; 9(1):3-11

https://aeji.journals.ekb.eg/

http://mis.zu.edu.eg/ajied/home.aspx 
12- Alessandro F., Giuseppina B., Marcello D, Patrizia I, Alessio F, Salvator D, et. al. Reactivation of hepatitis $B$ virus in cancer patients treated with chemotherapy for solid tumors. Is the prophylaxis really required? Digestive and Liver Disease 2017; 49: 197-201.

13- Kawsar H.I., Shahnewaz J., Gopalakrishna K.V., Spiro TP., Daw HA. Hepatitis B reactivation in cancer patients: role of pre-chemotherapy screening and antiviral prophylaxis. Clinical Advances in Hematology and Oncology 2012; 10:370-8.

14- Yoo J.J., Cho E.J., Cho Y.Y. Efficacy of antiviral prophylaxis in HBsAg-negative, anti$\mathrm{HBc}$ positive patients undergoing hematopoietic stem cell transplantation. Liver International2015;35:2530-6.
15- Tang W., Chen .L, Zheng R., Pan L. Prophylactic effect of lamivudine for chemotherapy-induced hepatitis $\mathrm{B}$ reactivation in breast cancer: a meta-analysis. PLoS One 2015; 10:e128673.

16- Brennan MF. Uncomplicated starvation versus cancer cachexia. Cancer Res 1977;37:23592365 ,

17- Pedersen LM, Sorensen PG. Increased urinary albumin excretion rate in breast cancer patients. Acta Oncol 2000; 39:145-149.

18- Vigano A, Bruera E, Jhangri GS. Clinical survival predictors in patients with advanced cancer. Arch Intern Med 2000;160:861-868 